Pustaka Karya: Jurnal Ilmiah Ilmu Perpustakaan dan Informasi Vol. 8 No. 1, Juni 2020, Hal. 15-23

http://dx.doi.org/10.18592/pk.v7i15.3710

ISSN (p) : 2089-5216 | ISSN (e) : 2723-7699

\title{
Representasi perpustakaan dan pustakawan dalam film serial animasi upin ipin “aku sebuah buku”: sebuah analisis semiotik \\ ${ }^{1}$ Prisca Budi Juvitasari \\ ${ }^{1}$ UIN Tulungagung \\ ${ }^{1} \mathrm{Jl}$. Mayor Sujadi No.46, Kudusan, Plosokandang, Kec. Kedungwaru, Kabupaten Tulungagung, Jawa Timur 66221 \\ Email:1ㅁiscajuvita@gmail.com
}

\begin{abstract}
Film is a media representation that can describe something, including a library. Assessing library representation media such as film would be significant to know libraries concept in communities. This study describes the representation of libraries and librarians in the animated series Upin and Ipin: I'm a Book. This study uses descriptive qualitative research using semiotic analysis using the Charles Sanders Peirce model, which aims to describe the representation of libraries and librarians in films with the principles of reality and representation. The conclusion of this study explains that the library is described as a crowded place with various types of visitors. While the librarian is described as being angry when he sees books placed out of place, but still friendly when serving visitors using conventional systems.
\end{abstract}

Keywords: animated series; library; librarian; representation

\begin{abstract}
ABSTRAK
Film merupakan suatu media representasi untuk menggambarkan sesuatu termasuk perpustakaan. Representasi perpustakaan dalam media seperti film menjadi penting untuk dapat mengetahui konsep perpustakaan yang berada dalam pikiran masyarakat. Penelitian ini menjelaskan tentang representasi perpustakaan dan pustakawan dalam film serial animasi Upin dan Ipin "Aku Sebuah Buku". Teknik penelitian yang digunakan yaitu kualitatif deskriptif dengan menggunakan analisis semiotik teori Charles Sanders Peirce yang bertujuan untuk mendeskripsikan representasi perpustakaan dan pustakawan yang ada dalam film dengan menggunakan prinsip realitas dan representasi. Kesimpulan dari penelitian ini adalah perpustakaan digambarkan sebagai tempat yang ramai dengan berbagai macam jenis pengunjung. Sedangkan pustakawan digambarkan sebagai seorang laki-laki yang memiliki sifat pemarah dan emosional ketika melihat buku diletakkan tidak pada tempatnya, namun tetap bersikap ramah saat melayani pengunjung dengan menggunakan sistem yang masih konvensional.
\end{abstract}

Kata Kunci: perpustakaan; pustakawan; representasi; serial animasi

\section{PENDAHULUAN}

Pada masa globalisasi saat ini, kebutuhan informasi merupakan bagian dari kebutuhan primer yang dimiliki oleh setiap orang. Setiap orang mempunyai kebutuhan informasi yang berbeda-beda. Perpustakaan menjadi salah satu rujukan utama untuk memenuhi kebutuhan informasi. Berbagai jenis koleksi mulai dari koleksi tercetak hingga koleksi digital telah disediakan oleh perpustakaan. Koleksi yang ada juga disusun secara sistematis agar pengunjung bisa lebih mudah mencari koleksi yang dibutuhkan.

Perpustakaan menurut Undang-Undang No 43 Tahun 2007 diartikan sebagai institusi pengelola koleksi karya tulis, karya cetak, dan/atau karya rekam secara profesional dengan sistem yang baku 
guna memenuhi kebutuhan pendidikan, penelitian, pelestarian, informasi dan rekreasi para pengguna. Dalam undang-undang, juga mengakui terkait profesi seorang pustakawan atau orang yang mempunyai kompetensi dari pendidikan atau pelatihan kepustakawanan dan mempunyai tugas serta tanggung jawab untuk melaksanakan kegiatan pengelolaan dan pelayanan perpustakaan.

Selain Undang-Undang, perpustakaan juga turut diakui keberadaanya melalui media-media seperti film. Beberapa film telah mengambil setting ataupun cerita terkait dunia perpustakaan. Film merupakan karya fiksi yang merupakan karya imajinatif yang dilandasi kesadaran dan tanggung jawab dari segi kreativitas sebagai karya seni. Selain membentuk konstruksi masyarakat akan suatu hal, film juga merupakan realitas yang tumbuh dan berkembang dalam masyarakat kemudian memproyeksikannya ke atas layar (Sobur, 2006).

Sedangkan film animasi menurut Beaver (2015), merupakan film yang digambar secara individual dan difoto frame demi frame. Setiap frame memiliki sedikit perbedaan dengan frame lainnya sehingga dapat menimbulkan ilusi seperti sedang bergerak ketika ditampilkan secara cepat. Jadi film merupakan media yang dapat menggambarkan representasi terhadap suatu objek. Representasi yang ditampilkan dalam sebuah film tidak terlepas dari realitas yang ada dalam masyarakat.

Perpustakaan dan pustakawan merupakan salah satu objek yang bisa di representasikan dalam sebuah film. Banyak penelitian yang menjadikan perpustakaan dan pustakawan sebagai salah satu objek representasi dalam sebuah film. Salah satunya Azzasyofia pada tahun 2012 yang meneliti film dengan judul "The Librarians: Quest for the Spear". Dalam film tersebut perpustakaan digambarkan memiliki koleksi benda-benda pusaka yang berpengaruh dalam sejarah perkembangan dunia. Selain itu penelitian Hermawan dengan judul Konsepsi Perpustakaan dalam Film "Heartbreak Library" yang menggambarkan konsep perpustakaan dalam menyediakan berbagai macam fasilitas untuk pengguna.

Berbeda dengan penelitian Azzasyofia, penelitian ini akan berfokus pada media film serial animasi yaitu Upin dan Ipin. Serial animasi tersebut bercerita tentang anak- anak yang senang saat berkunjung ke perpustakaan. Mereka datang ke perpustakaan dengan berbagai macam tujuan salah satunya membaca buku. Serial animasi ini juga menggambarkan pengunjung yang melakukan kegiatan vandalisme atau merusak koleksi yang ada di perpustakaan, baik secara sadar ataupun tidak dan pusatakawan yang rutin melakukan perawatan koleksi. Serial animasi ini memberikan banyak pengetahuan terkait dunia perpustakaan dan cara untuk menumbuhkan minat baca kepada anak. Oleh karena itu peneliti tertarik untuk meneliti representasi perpustakaan dan pustakawan dalam film serial animasi "Upin dan Ipin: Aku Sebuah Buku”.

\section{METODE PENELITIAN}

Penelitian ini menggunakan pendekatan kualitatif melalui analisis semiotika untuk menganalisis objek yang diteliti yaitu perpustakaan dan pustakawan. Penelitian ini mengacu pada teori Charles Sanders Peirce yang mendefinisikan semiotik sebagai hubungan antara tanda (sign), obyek (object), dan interpretan (intrepretant). Sign (tanda) merepresentasikan sebuah objek atau referent dalam benak interpreter. Charles Sanders Peirce menunjuk representasi objek oleh tanda sebagai interpretant. Unit analisisnya adalah sistem tanda, yakni pakaian (costume), lingkungan, ekspresi dan perilaku, serta tata visualisasi alur cerita yang ada dalam serial animasi Upin dan Ipin Aku Sebuah Buku. 
III.

HASIL DAN PEMBAHASAN

Penggambaran perpustakaan keliling dan pustakawan dalam serial animasi upin ipin aku sebuah buku awal cerita serial animasi upin dan ipin aku sebuah buku bermula dari perpustakaan keliling. Lokasi mobil perpustakaan keliling terletak di pinggir jalan depan taman kanak-kanak tadika mesra. Kemudian cerita aku sebuah buku mengambil setting di dalam gedung perpustakaan.

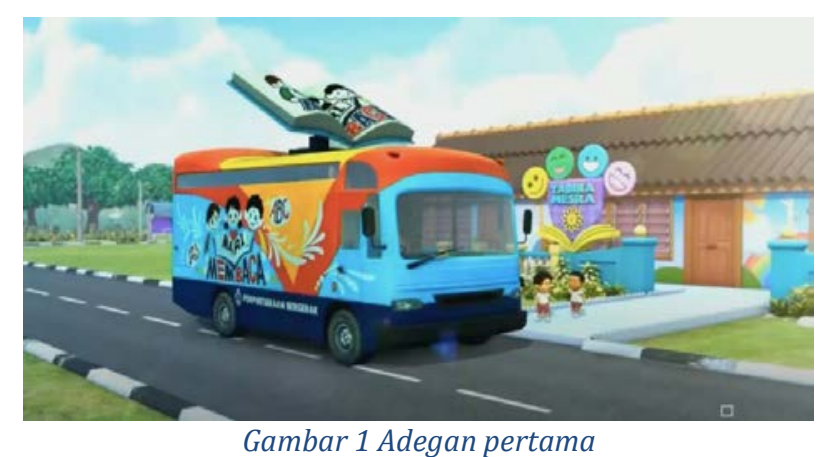

Perpustakaan keliling digambarkan dalam sebuah mobil yang berwarna biru dengan hiasan bertema buku yang berhenti di pinggir jalan depan sekolah Tadika Mesra. Teknik pengambilan gambar yang digunakan adalah teknik Long Wide Shot. Penggunaan teknik ini bertujuan untuk menunjukkan tata letak mobil perpustakaan keliling serta pengunjung perpustakaan (Zul dan Ijat) yang sedang berbaris mengantri untuk memasuki mobil perpustakaan pada pagi hari.

Dalam adegan ini menggambarkan bahwa anak-anak diajarkan untuk menumbuhkan minat baca sedari kecil dengan cara membiasakan diri untuk datang ke perpustakaan. Representasi adegan ini adalah dengan menerapkan budaya antri kepada anak-anak saat akan memasuki mobil perpustakaan keliling. Dalam gambar tersebut juga menunjukkan upaya sosialisasi kepada masyarakat untuk mengajarkan kepada anak-anak agar gemar membaca sedini mungkin dengan cara rajin mengunjungi perpustakaan. Karena dengan membaca, maka akan mendapatkan berbagai macam informasi.

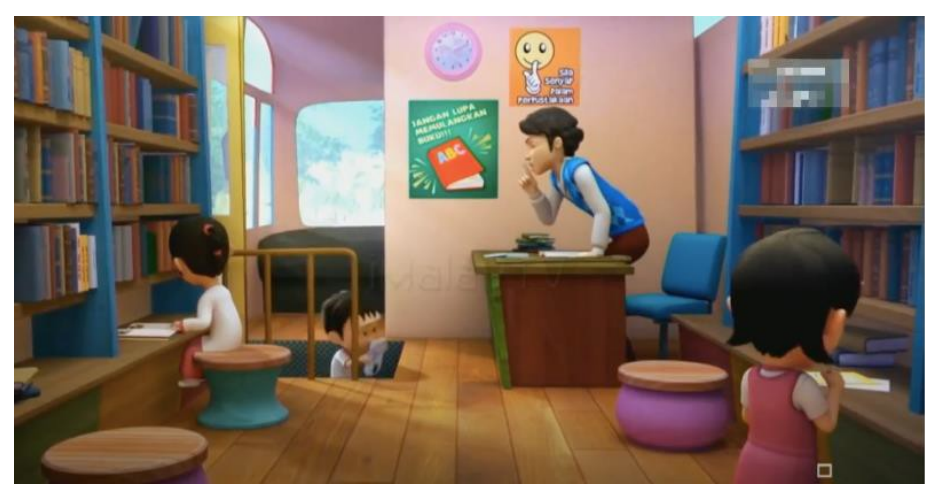

Gambar 2 Adegan kedua

Pada gambar kedua, teknik pengambilan gambar yang dilakukan adalah teknik Long Shot. Objek kamera adalah memperlihatkan pengunjung perpustakaan (defi) salah satu siswi yang sedang membaca buku, (susanti) yang sedang memilih buku, dan seorang pustakawan yang sedang membaca. Ini merepresentasikan bahwa mobil keliling tersebut menggunakan sistem open access, yang memperbolehkan user mengakses informasi sendiri. Keadaan mobil perpustakaan dalam gambar adegan tersebut terlihat bersih. Tempat duduk yang didesain unik dengan berbagai warna, serta rak koleksi buku yang berwarna biru dan coklat bertujuan untuk meningkatkan minat baca pengunjung. Selain itu, terdapat poster himbauan yang ditempatkan pada dinding bus. Poster yang 
pertama berisi anjuran untuk tidak membuat suara berisik ketika berada di perpustakaan dan poster yang kedua berisi anjuran untuk mengembalikan buku setelah selesai meminjam.

Representasi mobil keliling menunjukkan adanya berbagai macam warna yang digunakan pada setiap furnitur agar anak-anak senang ketika berada di mobil perpustakaan keliling dan semangat untuk membaca buku yang telah disediakan. Sedangkan isi himbauan pada poster pertama menunjukkan bahwa anak-anak dibiasakan untuk lebih disiplin dalam mengembalikan buku yang telah dipinjam tepat waktu, sehingga tidak terkena denda pengembalian buku. Dalam poster kedua menunjukkan bahwa anak-anak mulai dikenalkan pada aturan untuk tidak boleh membuat suarasuara yang bisa mengganggu orang lain saat sedang berada di dalam perpustakaan. Perpustakaan keliling tersebut juga menerapkan sistem open access sehingga pengunjung langsung datang ke rak koleksi untuk mencari koleksi buku yang diinginkan.
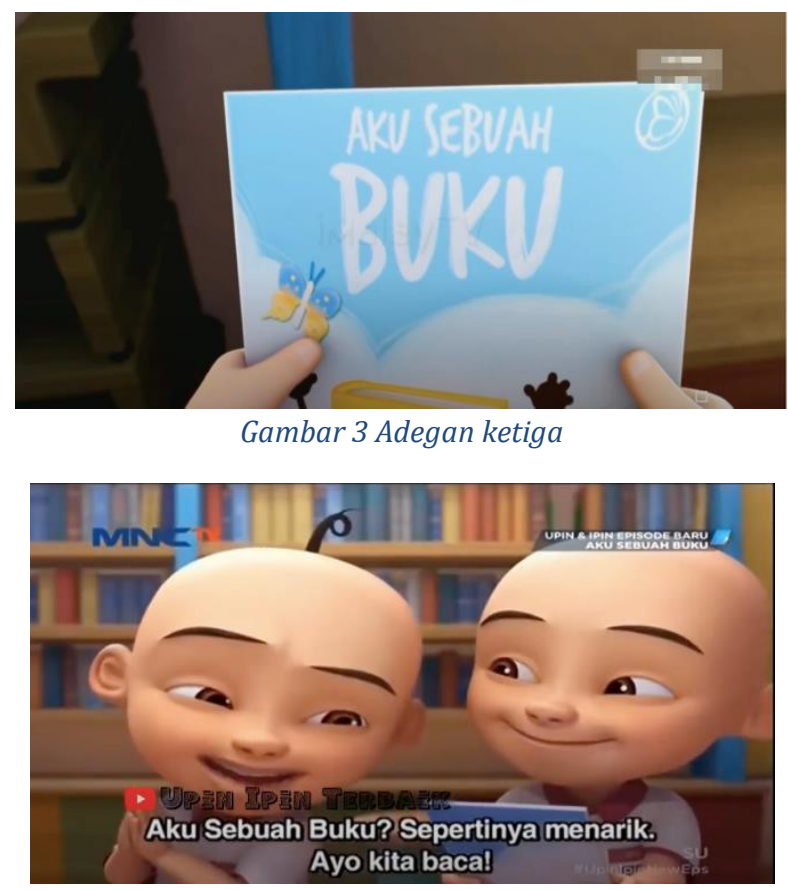

Pada gambar ketiga, teknik pengambilan gambar yang dilakukan adalah Close Up. Objek kamera adalah sebuah buku yang berjudul aku sebuah buku. Pengambilan gambar ini menghasilkan sebuah objek yang terlihat besar sehingga informasi yang ditunjukkan detail tentang judul buku yang di ambil oleh pengunjung perpustakaan (Ipin) sebagai tokoh utama dari rak koleksi. Berikutnya, pada gambar kedua, kamera melakukan teknik pengambilan gambar Medium Shot yang menggambarkan pengunjung perpustakaan (ipin) sedang membawa buku yang berjudul “Aku Sebuah Buku”, kemudian pengunjung perpustakaan lain (Upin) datang mendekat dan membaca buku yang sedang dibawa oleh Ipin, dan Upin tertarik dengan judul buku tersebut. Kemudian Upin mengajak Ipin untuk membaca buku tersebut bersama. Representasi dari gambar adegan tersebut menunjukkan bahwa anak-anak senang terhadap koleksi yang ada di perpustakaan dan senang membaca buku dengan kesadaran sendiri. 


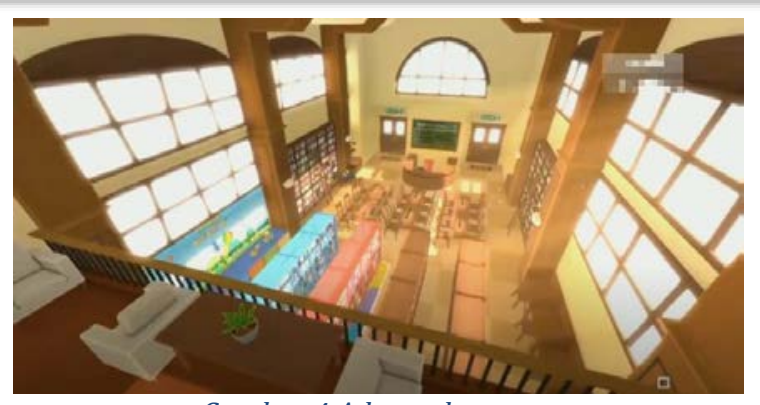

Gambar 4 Adegan keempat

Setelah membaca buku bersama, Upin dan Ipin berimajinasi mejadi sebuah buku yang berada di kotak besar berwarna coklat dan baru tiba di perpustakaan. Teknik pengambilan gambar adegan keempat ini adalah Full Shoot. Hal ini bertujuan untuk menggambarkan keadaan di dalam gedung perpustakaan yang memiliki bangunan luas dan bersih serta mempunyai warna dominan coklat dengan perabot yang terbuat dari kayu. Perpustakaan ini bernama perpustakaan ilmu dan memiliki 2 lantai. Lantai yang pertama terdapat rak koleksi, kursi dan meja baca, dan meja sirkulasi. Perpustakaan didesain menggunakan warna coklat. Mulai dari rak koleksi buku yang berjejer rapi, kursi dan meja yang tertata rapi, meja sirkulasi yang bersih dan pintu perpustakaan. Di samping meja sirkulasi terdapat rak yang berwarna coklat sebagai tempat tanaman hias. Sedangkan di lantai 2 hanya terdapat meja baca yang digunakan untuk membaca mandiri.

Penggunaan warna coklat secara umum mampu menghadirkan kesan alami, tetapi juga klasik (antik). Sedangkan secara psikologis mengesankan kenyamanan. Dalam gambar adeagn tersebut, perpustakaan direpresentasikan sebagai gedung yang sudah tua. Tetapi, secara psikologis penggunaan warna coklat digunakan oleh perpustakaan agar pengunjung bisa merasa tenang dan nyaman untuk menghabiskan waktu yang lama di dalam perpustakaan. Setting tempat ini menggunakan suasana perpustakaan yang tidak tersentuh dengan teknologi, sedangkan kenyataannya serial animasi ini di produksi pada Desember 2018 yang mana perkembangan perpustakaan di Malaysia tergolong pesat. Hal ini tidak sejalan dengan perpustakaan yang digambarkan dalam serial animasi ini yang masih mempertahankan hal-hal yang bersifat konvensional seperti tidak adanya teknologi dalam perpustakaan ini.

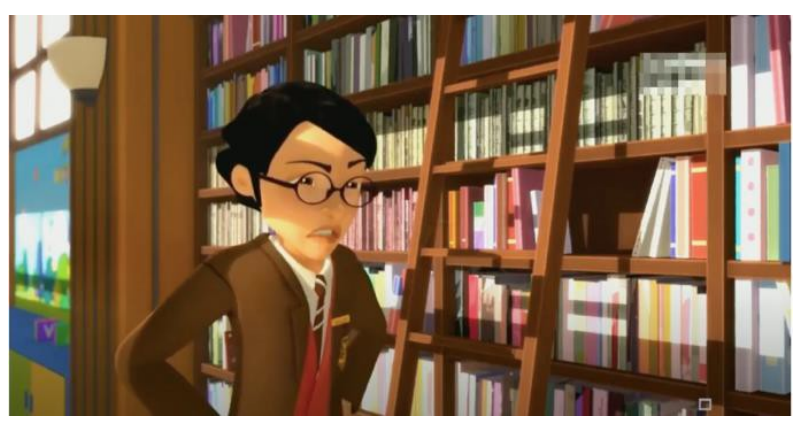

Gambar 5 Adegan kelima

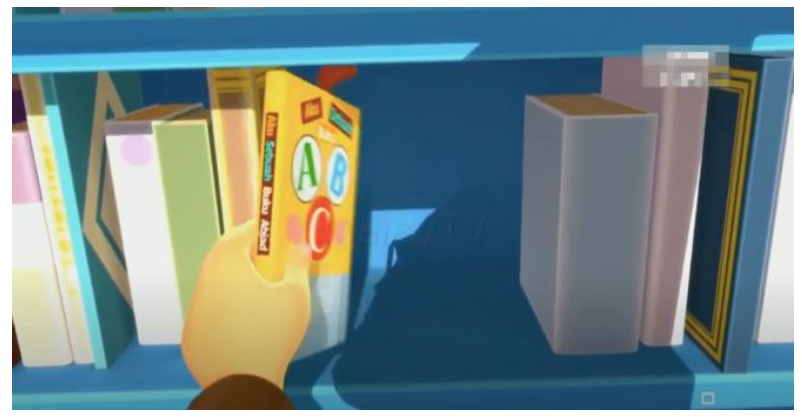


Teknik pengambilan gambar adegan tersebut menggunakan teknik Medium Shoot. Dalam adegan ini seorang pustakawan digambarkan sebagai seorang laki-laki yang memiliki model rambut rapi, dan menggunakan kacamata. Dari segi kostum, pakaian yang dipakai rapi dan sesuai dengan trend mode saat ini. Dalam gambar adegan tersebut, pustakawan digambarkan sedang marah saat melihat buku yang berserakan. Ini merepresentasikan bahwa sampai saat ini pustakawan identik dengan seseorang yang memiliki sifat pemarah dan emosional ketika melihat buku diletakkan tidak pada tempatnya.

Pada gambar adegan kedua menggunakan teknik Close Up yang menunjukkan pustakawan sedang menata buku di rak koleksi. Pada gambar tersebut, koleksi buku-buku yang diletakkan di rak terlihat tidak memiliki call number pada punggung koleksi. Makna konotasi pada gambar adegan tersebut adalah kondisi perpustakaan yang digambarkan masih belum menerapkan call number pada punggung buku. Kondisi ini juga terjadi di beberapa perpustakaan daerah yang masih belum menerapkan kegiatan (klasifikasi atau katalogisasi) pada setiap koleksi yang dimiliki, tetapi sudah di display pada rak koleksi. Pada sisi lain, koleksi yang dimiliki juga terbatas pada koleksi cetak seperti buku, dan belum memiliki koleksi elektronik.

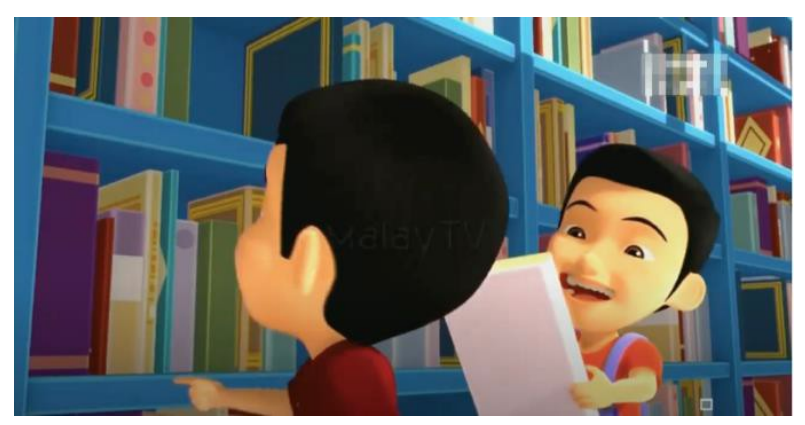

Gambar 6 Adegan keenam

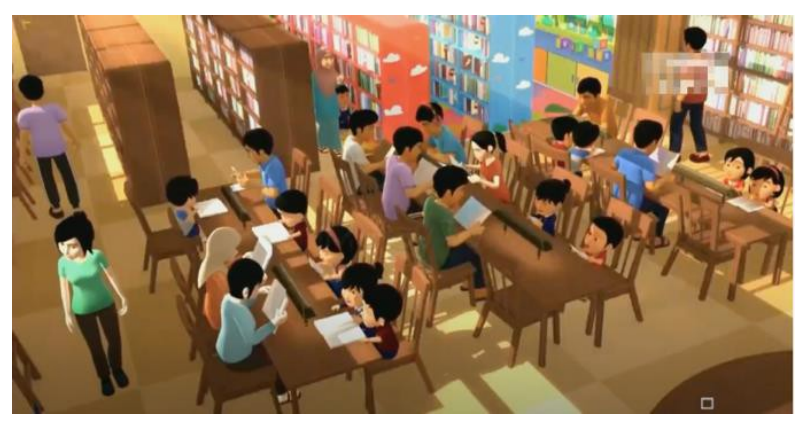

Gambar pertama diambil menggunakan teknik Medium Shoot yang menunjukkan bahwa ada dua pengunjung perpustakaan yang terlihat senang saat berada di antara koleksi yang ada di perpustakaan. Pengunjung pertama sedang menentukan akan mengambil koleksi buku apa, sedangkan yang lain sudah mendapatkan buku yang diinginkan. Representasi yang ditunjukkan bahwa pengunjung senang berada di perpustakaan dan membaca buku yang mereka inginkan tanpa adanya paksaan. Selain itu perpustakaan ini menggunakan sistem open access yang memperbolehkan users untuk langsung datang ke rak koleksi dan memilih koleksi yang dibutuhkan sendiri. Ini menunjukkan bahwa users sudah mengetahui dengan benar dimana letak koleksi yang mereka inginkan karena sering berkunjung ke perpustakaan.

Pada gambar kedua diambil menggunakan teknik Full Shoot yang bertujuan untuk memperlihatkan perpustakaan tersebut telah ramai dikunjungi oleh berbagai macam pengunjung. Rak koleksi dalam gambar tersebut terbagi menjadi beberapa warna yaitu warna coklat dan juga 
warna merah serta biru. Keadaan ini merepresentasikan bahwa perpustakaan tersebut merupakan jenis perpustakaan umum yang memiliki pengunjung mulai dari anak-anak, remaja hinga orang dewasa. Warna rak koleksi yang berbeda menunjukkan perbedaan jenis koleksi. Warna rak coklat ditujukan untuk koleksi remaja atau orang dewasa, sedangkan untuk warna rak biru dan merah ditujukan untuk koleksi anak-anak. Perbedaan warna rak koleksi ini digunakan agar pengunjung yang datang tidak mengalami kesulitan saat mencari koleksi yang dibutuhkan.
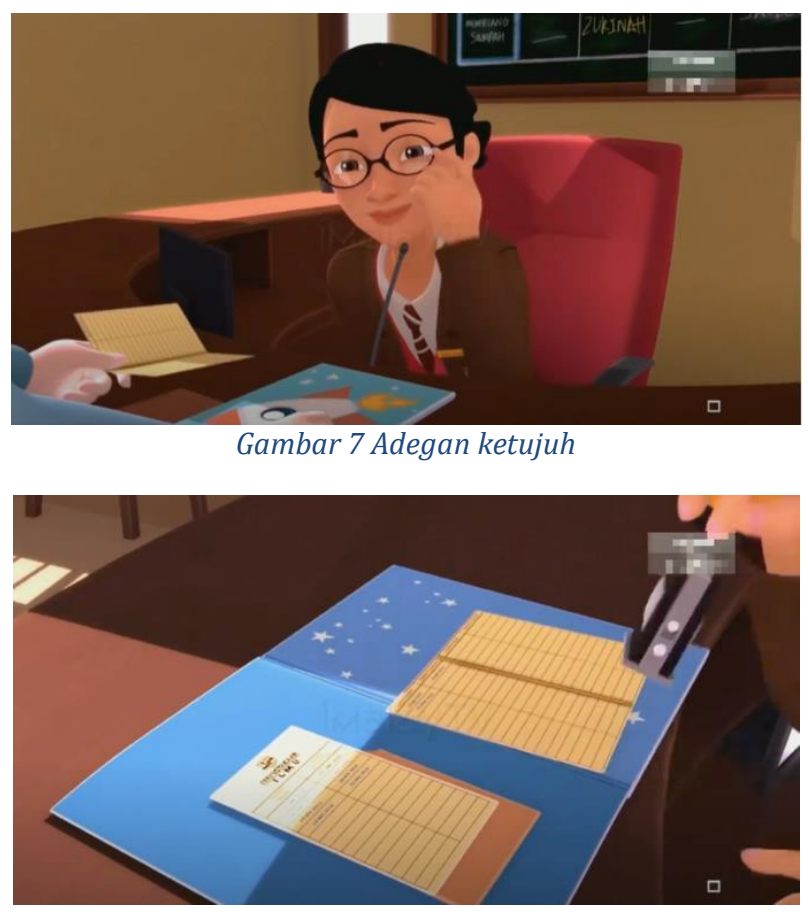

Pada gambar ketujuh, adegan pertama menunjukkan seorang pengunjung yang sedang berada di meja sirkulasi untuk menyerahkan koleksi kepada pustakawan agar koleksi tersebut bisa dipinjam. Pengambilan gambar Medium Shoot ini secara tidak langsung menunjukkan bahwa adanya interaksi yang baik antara pengunjung dengan pustakawan. Sebelum meminjam buku, pengunjung menanyakan terlebih dahulu kepada pustakawan apakah koleksi tersebut bisa dipinjam. Kemudian pustakawan memberikan jawaban dengan ramah. Representasi dalam serial animasi ini menampilkan bahwa pustakawan adalah sosok yang ramah saat memberikan pelayanan kepada pengguna.

Gambar kedua menggunakan teknik close up yang bertujuan menjelaskan deskripsi objek secara detail, yaitu kartu buku yang terdapat pada bagian belakang untuk mencatat nomor anggota, dan tanggal kembali serta kartu peminjaman untuk mencatat judul buku yang dipinjam, serta tanggal pengembalian. Selanjutnya pustakawan terlihat masih menggunakan cap stempel tanggal manual untuk memberikan tanggal pengembalian pada kartu buku dan kartu peminjaman. Secara keseluruhan gambar tersebut merepresentasikan bahwa pustakawan masih menggunakan sistem peminjaman secara konvensional. Hal ini terlihat dari pengunjung yang masih datang ke meja sirkulasi untuk melakukan proses peminjaman buku dan untuk proses peminjaman masih menggunakan kartu buku dan juga kartu peminjaman. 


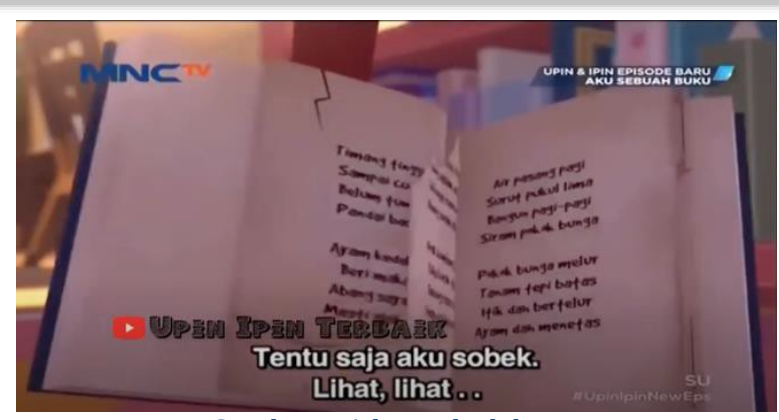

Gambar 8 Adegan kedelapan

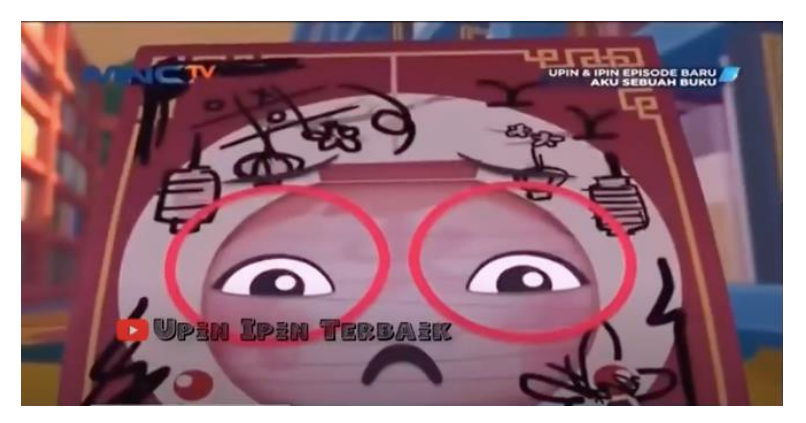

Teknik pengambilan kedua gambar tersebut menggunakan teknik close up yang bertujuan untuk memperlihatkan kerusakan yang terjadi pada koleksi buku di perpustakaan. Kedua gambar adegan tersebut menunjukkan bahwa koleksi di perpustakaan sering mengalami kerusakan yang diakibatkan oleh pengguna. Berbagai jenis kerusakan terjadi pada koleksi buku mulai dari merobek koleksi, mencoret, atau memberikan noda makanan pada koleksi buku yang tersedia. Keadaan ini merepresentasikan bagaimana kondisi koleksi perpustakaan yang masih terjadi sampai saat ini, dimana sering terjadi vandalisme atau kerusakan terhadap bahan koleksi yang dilakukan oleh pengguna. Makna konotasi yang ada pada kedua gambar ini adalah pengguna tidak bisa menjaga koleksi yang ada di perpustakaan dengan baik. Hal ini terlihat dari aturan yang tidak ditaati oleh pengguna sehingga menyebabkan koleksi buku menjadi kotor dan rusak.

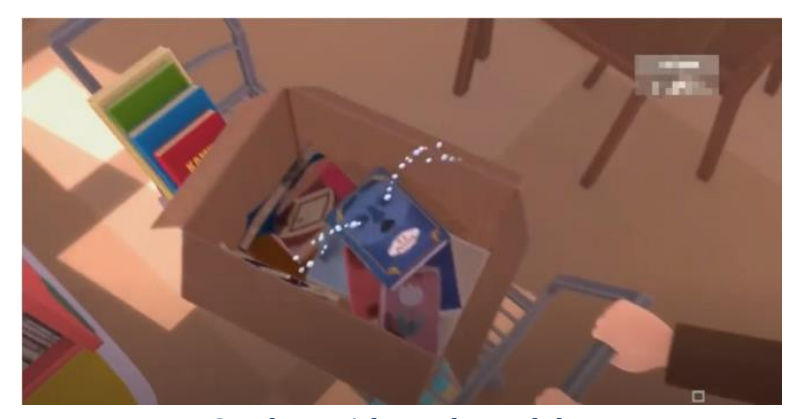

Gambar 9 Adegan kesembilan

Pengambilan gambar dilakukan menggunakan teknik medium shot untuk memperlihatkan kegiatan yang dilakukan oleh pustakawan sebelum membuka perpustakaan, yaitu mengecek koleksi-koleksi yang ada. Jika ada koleksi yang rusak, maka langsung dimasukkan ke dalam sebuah kotak untuk di perbaiki. Adegan ini direpresentasi sebagai suatu tindakan yang dilakukan oleh pustakawan untuk terus menjaga koleksi yang ada dengan cara melakukan perawatan bahan pustaka secara rutin dan berkala agar koleksi tersebut bisa digunakan kembali dan informasi yang ada di perpustakaan bisa tersampaikan kepada pengguna perpustakaan. Dengan demikian, adegan ini mengajak kepada masyarakat untuk selalu menjaga dan menghargai setiap koleksi yang ada di perpustakaan dengan cara tidak melakukan kegiatan vandalisme terhadap koleksi perpustakaan. 


\section{KESIMPULAN}

Perpustakaan dalam serial animasi Upin dan Ipin “Aku Sebuah Buku” digambarkan sebagai tempat yang memiliki desain kurang menarik dan identik dengan warna cokelat. Meskipun bergitu, perpustakaan tersebut tetap ramai dengan pengunjung setiap hari. Berbagai jenis pengunjung yang datang ke perpustakaan. Mulai dari anak- anak, remaja hingga orang dewasa berkunjung ke sana. Selain perpustakaan, serial animasi ini juga menampilkan seorang pustakawan yang digambarkan sebagai laki-laki berkacamata, memiliki gaya rambut rapi, mudah marah saat melihat buku berserakan, namun tetap ramah saat melayani pengguna. Adegan yang ditampilkan dalam film ini menunjukkan bahwa pengunjung memiliki tujuan yang berbeda-beda saat berada di perpustakaan. Ada yang datang untuk membaca buku atau merusak koleksi buku yang ada dengan cara mencoratcoret buku atau membawa makanan ke dalam perpustakaan. Secara tidak langsung film ini mengajak kepada masyarakat untuk menjaga dan menghargai koleksi buku di perpustakaan serta mulai menumbuhkan budaya gemar membaca.

\section{DAFTAR PUSTAKA}

Azzasyofia, M. (2012). Representasi Perpustakaan dan Pustakawan dalam Film The Librarian: Quest For The Spear. Universitas Indonesia: Depok.

Beaver, F. (2015). Dictionary of Film Terms: The Aesthetic Companion to Film Analysis. 5th ed. New York: Peter Lang.

Hermawan, A. (2017). Konsepsi Perpustakaan dalam Film Heartbreak Library. UIN Sunan Kalijaga: Yogyakarta.

Fadhli, R. (2019). Representasi Perpustakaan dan Pustakawan dalam Film The Night At The Museum 3. Universitas Negeri Yogyakarta: Yogyakarta.

Fauzi, M. I \& Nina M. (2019). Representasi Perpustakaan dalam Serial Animasi Avatar. Universitas Indonesia: Depok.

Sobur, A. (2006). Analisis Teks Media Suatu Pengantar untuk Analisa Wacana, Analisis Semiotik dan Analisis Framing. Bandung: Remaja Rosdakarya.

Republik Indonesia. (2007). Undang-Undang No. 43 Tahun 2007 tentang Perpustakaan. Jakarta 